\title{
Morphometric Dimentions of the Genitalia of Savanna Brown Goats between Day 24 and 30 Postpartum.
}

\author{
Mohammed Kawu ${ }^{1}$, Lawrence Eduvie ${ }^{2}$, Clarence Lakpini ${ }^{2}$ and Joseph Ayo ${ }^{1}$ \\ ${ }^{I}$ (Department of Physiology and Pharmacology, Faculty of Veterinary Medicine, Ahmadu Bello University, \\ Zaria, Nigeria) \\ ${ }^{2}$ (National Animal Production Research Institute, Shika, Ahmadu Bello University, Zaria, Nigeria)
}

\begin{abstract}
This study was carried out to determine changes in ovarian and uterine dimensions in Savanna Brown (SB) goats between days 24 and 30 postpartum (pp). The mean ( \pm sem) weight of the right ovary (ROV) was significantly higher $(P<0.05)$ at day $28 \mathrm{pp}$. The diameter of the largest follicle in the ROV was greater $(P$ $<0.05)$ at day $28 \mathrm{pp}$. The weight of follicular fluid (FF) from all follicles in both ovaries was heavier $(P<0.05)$ at day $28 \mathrm{pp}$. The number of follicles $\geq 0.3 \mathrm{~cm}$ in diameter in the $R O V$ was higher $(P<0.05)$ at day $30 \mathrm{pp}$ than day 26 pp. Mean weight of FF from the left ovary $(L O V)$ was heavier $(P<0.05)$ than from the ROV during the period of study. The inter-caruncular distance in both the right (Rh) and left (Lh) uterine horns was longer $(P<0.05)$ at day $30 \mathrm{pp}$. The left oviduct was longer $(P<0.05)$ than the right oviduct at day $30 \mathrm{pp}$. It is concluded that pp ovarian follicle activity was higher in the ROV than LOV and inter-carunucular distance and left oviductal length were significantly longer between days 28 and $30 \mathrm{pp}$.
\end{abstract}

Keywords: Dimentions, genitalia, goats, morphometry, postpartum.

\section{Introduction}

The estimated population of goats in Nigeria was 34.5 million [1]. The Savanna Brown goat (also known as 'Red Sokoto' goat) constitute about sixty percent of the Nigerian goat population [2]. They are yearround breeders with oestrous cycle length and oestrus duration ranging from $19-21$ days and $21-26$ hours, respectively $[3,4]$. Uterine involution is the time required for a recent pregnant uterus to resume the condition in which fertilization, implantation and embryonic development can proceed [5]. Completion of macroscopic uterine involution is defined by similarity in pp uterine horn length or with the uterine dimensions of empty nonpostpartum animals of the same breed [6]. Factors that influence uterine involution include parity, suckling and season $[7,8,6]$. Early resumption of ovarian activity and exogenous administration of progesterone also affect uterine involution $[9,6]$. Completion of uterine involution and first pp oestrus in SB goats occur between $24-28$ days [2], and 19 - 30 days pp [10], respectively. Studies on gross ovarian features of SB goats had been restricted mainly to abattoir specimens [11,12]. Therefore, the purpose of this study was to determine morphometric changes in the genitalia of SB goats between pp days 24 and 30, a period that coincides with the completion of uterine involution and first pp oestrus in the SB goat.

\subsection{Animals and management}

\section{Materials and Methods}

Eight multiparous ( $2-3$ parity) pp SB does aged between $2-3$ years and weighing between $15-25$ $\mathrm{kg}$ were used for the study. They were sourced from the research stock of the Department of Veterinary Physiology and Pharmacology, Ahmadu Bello University, Zaria. The animals were housed in semi-open concrete floor pens and grazed on natural pasture supplemented with maize offal and cotton seed cake.

\subsection{Measurement of genital dimensions}

Following parturition, two animals each were allotted for slaughter on days 24, 26, 28 and $30 \mathrm{pp}$. On the appointed day, two animals each were slaughtered, skinned and flayed using standard procedure. A mid-line incision was made between the mammary quarters and the genitalia consisting of the ovaries, uterus, oviducts and cervix were exteriorized, resected and freed of all ligamental and fat tissues. Thereafter, the following dimensions were taken with a measuring tape as described by earlier workers $[13,14,6]$ :

\subsection{Ovarian dimensions}

Length of the ovary was measured as the distance between the anterior and posterior surfaces, breadth, as distance between the medial and lateral poles and, height, as distance between the attached and free borders of the ovary; weight of intact ovary, volume of intact ovary (i.e. the volume of water displaced by the ovary when placed in a $5 \mathrm{ml}$ graduated test-tube filled with water), weight of ovary after removal of follicular fluid 
(FF), number of follicles on each ovary classified according to their diameters as small $(<0.3$ in diameter) and large ( $\geq 0.3 \mathrm{~cm}$ in diameter), diameter of the largest follicle taken along its longest axis, volume of FF from the largest follicle and from all follicles (obtained by aspiration with a $1 \mathrm{ml} 25 \mathrm{G}$ insulin syringe), and the weight of FF from all follicles (obtained by subtracting the ovarian weight without FF from the weight of the intact ovary).

\subsection{Uterine dimensions}

Length of uterine horn was taken from the internal bifurcation to the uterotubal junction (after careful dissection from the external bifurcation with a scalpel blade), diameter of uterine horn at the level of the external bifurcation, thickness of the wall of uterine horn from the serosa to the endometrium at the level of the external bifurcation (through an incision made from the serosal surface to the uterine lumen), length of oviducts from the uterotubal junction to the junction of the fimbria, weight of oviducts after resection from the uterotubal junction, diameter of caruncle close to the external bifurcation, distance between two caruncles close to the external bifurcation, weight of the uterine horns after resection at the internal bifurcation and uterotubal junction, length of the uterine body from the internal bifurcation to the internal os of the cervix, diameter of the uterine body taken at the middle portion, weight of the uterine body after resection at internal bifurcation and internal os, length of the cervix from the internal to the external os, diameter of the cervix taken at the middle portion and weight of the cervix after resection at the internal and external os.

\subsection{Data analysis}

All data were expressed as mean ( $( \pm \mathrm{SEM})$ and compared using ANOVA and Turkey's post hoc test. The statistical package used was GraphPad Prism version 4.0 (2003) for Windows from GraphPad Software, San Diego, California, USA (www.graphpad.com). Values of $\mathrm{P}<0.05$ were considered significant.

\subsection{Ovarian Dimensions}

\section{Results}

The mean $( \pm$ sem $)$ weight of the ROV was significantly higher $(\mathrm{P}<0.05)$ at day $28 \mathrm{pp}$ than at days 24 , 26 and $30 \mathrm{pp}$, respectively (TABLE 1 ). The number of follicles in the ROV that were $\geq 0.3 \mathrm{~cm}$ in diameter was higher $(\mathrm{P}<0.05)$ at day 30 than day $26 \mathrm{pp}$ (TABLE 3). The diameter of the largest follicle in the ROV was greater $\quad(\mathrm{P}<0.05)$ at day 28 than on days 24,26 and $30 \mathrm{pp}$, respectively. The weights of FF from all follicles in the ROV and LOV were heavier $(\mathrm{P}<0.05)$ at day 28 than on days 24,26 and $30 \mathrm{pp}$, respectively (TABLE 4). Mean weight of FF from the LOV was heavier $(\mathrm{P}<0.05)$ than from the ROV during the period of study. Apart from these differences, other ovarian dimensions were not significantly different between the ROV and LOV and between days pp (TABLE 2).

\subsection{Uterine and oviductal dimensions}

The inter-caruncular distance in both the $\mathrm{Rh}$ and Lh was longer $(\mathrm{P}<0.05)$ at day 30 than on days 24,26 and $28 \mathrm{pp}$ (Table 7). The mean length of the left oviduct was longer $(\mathrm{P}<0.05)$ than the right oviduct at day 30 than on days 24, 26 and $28 \mathrm{pp}$, respectively. However, other dimensions measured were not significantly different between the Rh and Lh during the period of study (Table 5 and Table 6).

\section{Discussion}

The significantly higher weight, number of follicles $\geq 0.3 \mathrm{~cm}$ and diameter of largest follicle of the ROV as compared to the LOV is suggestive of higher ovarian pp activity in the ROV than in the LOV between days 24 and $30 \mathrm{pp}$. This finding agrees with earlier reports in other monotocous goat breeds [15,16], but differs with reports of similar activity between the ROV and LOV of dwarf goats $[17,18]$. This difference between the findings of our study and the latter reports on dwarf goats may be attributable to peculiarity of breed and stage of reproduction in which the studies were conducted. Also, the findings of our study may suggest a higher probability of the first pp ovulation occurring from the ROV than the LOV. Particularly, since mean ovarian size and endometrial thickness is reported to have a positive effect on reproductive activity [19]. The findings of this study may also imply that the frequency of pregnancy in the Lh is higher than in the Rh in SB goats because the ovary ipsilateral to the non-pregnant horn tends to resume activity earlier [20]. Another perspective to the present findings is that the presence of a future ovulatory follicle and a receding corpus luteum on contralateral ovaries tend to prolong the luteal phase of the subsequent cycle and favour the development of three follicular waves and a longer interovulatory interval [21]. This means that the SB goat may be predisposed to a relatively longer than normal first pp cycle.

Another significant observation in this study is that most of the changes in ovarian follicular activities occurred between days 28 and $30 \mathrm{pp}$. This is suggestive of a synergy between resumption of ovarian activity and the period of completion of uterine involution in the SB goats [2]. This means that a successful rebreeding programme involving oestrous synchronization and artificial insemination or natural breeding could 
be initiated around that period. Indeed, up to $80 \%$ oestrous response and non-return rates have been reported following commencement of oestrous synchronization with progestagen ear implants in SB goats between day 28 and $35 \mathrm{pp}$ [22].

The similarity in morphometric dimensions between the Rh and Lh observed in this study confirms that uterine involution is complete in SB goats during this period [2]. This is because completion of gross uterine involution is defined either by similarity in uterine born length or by comparing with the uterine dimensions of empty non-postpartum animals [6]. A similar period of completion of uterine involution as observed in this study had been reported in Canadian goats [23]. However, completion of uterine involution had also been reported to occur as early as day 19 in Balady goats [24,25]. This difference may not be unconnected with the effect of breed [26], and season [6], on the process of pp uterine involution.

The significant increase in mean inter-caruncular distance in both uterine horns and the length of the left oviduct at day $30 \mathrm{pp}$ may be a response to renewed stimulation by ovarian steroids due the significant level of ovarian follicular activity earlier observed during the period. Remodelling of caruncular and intercaruncular areas is critical to uterine involution and is influenced by the increase in oestrogen and progesterone receptor activities as uterine involution progresses [27].

The higher mean weight of FF from the LOV as compared to the ROV may be responsible for the increase in the length of the left oviduct as compared to the right oviduct. Again, this may be due to the uterotrophic effect of oestradiol reaching the left oviduct (considering that it had higher FF weight), possibly via a countercurrent mechanism between the ovarian artery and utero-ovarian vein as obtained in the transport of prostaglandin $\mathrm{F}_{2}$ alpha during luteolysis in domestic ruminants [28]. Ovarian steroid hormones enhance the interaction between a functional embryo and a receptive maternal uterus to ensure successful implantation $[29,30]$. Therefore, the increase in intercaruncular distance and oviductal length observed in this study may be due to uterotophic response to ovarian steroids in preparation for sperm capacitation, oocyte transport, implantation and pregnancy.

\section{Conclusion}

Based on the findings of this study, it is concluded that a rebreeding programme for SB goats could be designed to commence around days 28 and $30 \mathrm{pp}$ in order to take advantage of the utero-ovarian changes prevailing during that period that seem to favour ovulation and pregnancy establishment.

\section{References}

[1] RIMS Report, Nigerian Livestock Resources Survey (Resource Inventory and Management Limited, UK, 1992)

[2] O.O.A. Fasanya, E.C.I. Molokwu, D.S. Adegboye, and N.I. Dim, Gross and histological changes of the postpartum genitalia of Savanna Brown goat. Animal Reproduction Science, 14(1), 1987, 65-74.

[3] E.C.I. Molokwu, and M.O. Igono, Reproductive cycle of the Nigerian Savanna Brown Goat, Proc. III Int. Conf on Goat Production and Diseases. Tucson, Arizona, 1982, 312.

[4] N. Pathiraja, E.O. Oyedipe, E.O. Gyang, and A. Obasi, Plasma progesterone levels during oestrous cycle and their relationships with the ovulation rate in Red Sokoto (Maradi) goats, British Veterinary Journal, 147 (1), 1991, 57-62.

[5] G.L.Hunter, Increasing the frequency of pregnancy in sheep. II. Artificial control of rebreeding, and problems of conception and maintenance of pregnancy during the postpartum period. Animal Breeding Abstracts, 36 (4), 1968, 533-553.

[6] E. Rubianes, R. Ungerfeld, C. Vinoles, B. Carbajal, J. de Castro, and D. Ibarra, Uterine involution time and ovarian activity in weaned and suckling ewes. Canadian Journal of Animal Science, 76(1), 1996, 153-155.

[7] A. Okano, R. Fukuhara, Y. Shioya, and T. Obata, Morphological involution of postpartal uterus in Japanese Black cows. Bulletin of the Chugoku National Agricultural Experiment Station, Series B (25), 198, 1-10.

[8] P.A. Ottenacu, J.H. Britt, R.K. Braun, and R.W. Mellenberger, Relationships among type of parturition, type of discharge from genital tract, involution of cervix, and subsequent reproductive performance in Holstein cows. Journal of Dairy Science, 66(3), $1983,612-619$

[9] P.E. Sexton, and F.M. Bristol, Uterine involution in mares treated with progesterone and oestrdiol - 17Beta. Journal of the American Veterinary Medical Association, 186(3),1985, 252-256.

[10] O.O.A. Fasanya, E.C.I. Molokwu, L.O. Eduvie, and N.I. Dim, Dietary supplementation in the Savanna Brown goat. II. Gestation and postpartum activity in primiparous does. Animal Reproduction Science, 29(1), 1992,167-174.

[11] N. Pathiraja, and E.O. Oyedipe, (1985). Ovulation rate and reproductive wastage in traditionally managed Red Sokoto goats in Nigeria, Proc. Conf. Small Ruminant Production, Zaria, Nigeria, 1985, 264.

[12] T.O.M. Koomson, Studies on the female reproductive tract of indigenous sheep and goats. M.Sc diss., Ahmadu Bello University, Zaria, 1980

[13] L.O. Eduvie, C.O. Njoku, P.B. Addo, E.C.I. Molokwu, and D.I.K. Osori, Gross and histological changes in the reproductive tract of suckled and non-suckled postpartum cows. Journal of Animal Production Research, 4(1), 1984, 21-41.

[14] L.O. Eduvie, C.O Njoku, P.B. Addo, E.C.I. Molokwu, D.I.K. Osori, and P.B. Addo, Ovarian activity and changes in the suckled and non-suckled cows during the postpartum period. Journal of Animal Production Research, 5(2), 1985, 159-174.

[15] A.F. Alwan, S.Y.A. Al-Dahash, and H.A.R. Al-Baggal, Macroscopic study of the pregnant genitalia of Iraqi Goats. Small Ruminant Research, 11(4), 1993, 343-349.

[16] H.A.R. Al-Baggal, S.Y.A. AL-Dahash, and A.F. Alwan, Macroscopic study of the female genital system in Iraqi goats. Small Ruminant Research, 9(4), 1993, 341-346.

[17] V.H. Rao, and N.K. Bhattacharyya, Ovulation in Black Bengal goats. Journal of Reproduction and Fertility, 58 (1), $1980,67-69$.

[18] M.O. Akusu, A.I.A. Osuagwuh, J.U. Akpokodje, and G.N. Egbunike, Ovarian activities of the West African Dwarf goat (Capra hircus) during oestrus. Journal of Reproduction and Fertility, 78(2), 1986, 459-462. 
[19] F. M. Monteiro, M. E. Z. Mercadante, C. M. Barros, R. A. Satrapa, J. A. V. Silva, L. Z. Oliveira, N. Z. Saraiva, C. S. Oliveira, and J. M. Garcia, Reproductive tract development and puberty in two lines of Nellore heifers selected for postweaning weight, Theriogenology, 80(1), 2013, 10-17.

[20] G. G. Marion, and H. T. Gier, Factors affecting bovine ovarian activity after parturition, Journal of Animal Science, 27(6), 1968, $1621-1626$.

[21] O. J. Ginther, S. T. Bashir, V. G. Santos, and M. A. Beg, Contralateral ovarian location between the future ovulatory follicle and extant corpus luteum increases the length of the luteal phase and number of follicular waves in heifers, Theriogenology, 79(7), 2013, 1130-1138.

[22] M.U. Kawu, L.O. Eduvie, C.A.M. Lakpini, J.O. Ayo, and E.C.I. Molokwu, Preliminary observations on oestrous synchronization and early rebreeding using syncro-mate-B in the Red Sokoto (Maradi) goat, Proc. $28^{\text {th }}$ NSAP Conf. Moor Plantation, Ibadan, Nigeria, 2003, 30-33.

[23] A. H. Tielgy, M. Fathalla, M. A. Omar, and S. Al-Dahash, The clinical and morphological characteristics of the uterus of the goat during the period of involution, The Canadian Veterinary Journal, 23(4), 1982, 138-140

[24] M. M. Ababneh, and T. Degefa, Ultrasonic assessment of puerperal involution in Balady goats, Journal of Veterinary Medicine, A52 (5), 2005, 244-248.

[25] T. Degefa, M. M. Ababneh, and M. F Moustafa, Uterine involution in the post-partum Balady goat, Veterinarski Arhiv, 76(2), 2006, 119-133.

[26] E. Rubianes, and R. Ungerfeld, Uterine involution and ovarian changes in the early postpartum period in autumn-lambing Corriedale ewes. Theriogenology, 40(2), 1993, 365-372.

[27] C. A., Gray, M. D. Stewart, G. A. Johnson, and T. E. Spencer, Postpartum uterine involution in sheep: histoarchitecture and changes in endometrial gene expression, Reproduction, 125 (2), 2003, 185-198.

[28] G.H. Stabenfeldt, and A.P. Davidson, Reproduction and lactation, In: J.G. Cunningham (Ed.), Textbook of Veterinary Physiology, 3 (Philadelphia, Saunders/Elsevier, 2002) 374-406.

[29] D. D. Carson, I. Bagchi, S. K. Dey, E. C. Enders, A. T. Fazleabas B. A. Lessey, and K. Yoshinaga, Embryo implantation, Developmental Biology, 223(2), 2000, 217-237.

[30] S. K. Dey, H. Lim, S. K. Das, J. Reese, B. C. Paria, T. Daikoku, and H. Wang, Molecular cues to implantation, Endocrine Reviews, 25 (3), 2004, $341-373$

Table 1. Mean ( \pm SEM) Weights and Volumes of Ovaries of Savanna Brown Goats between Days 24 and 30 Postpartum

\begin{tabular}{|c|c|c|c|c|c|c|c|}
\hline \multirow{3}{*}{ Days PP } & \multirow{3}{*}{$\mathrm{n}$} & \multicolumn{4}{|c|}{ Weight of ovaries (g) } & \multicolumn{2}{|c|}{ Volume of ovaries (ml) } \\
\hline & & \multicolumn{2}{|c|}{ ROV } & \multicolumn{2}{|c|}{ LOV } & \multirow[t]{2}{*}{ ROV } & \multirow[t]{2}{*}{ LOV } \\
\hline & & $\mathrm{Wt}(+\mathrm{FF})$ & $\mathrm{Wt}(-\mathrm{FF})$ & $\mathrm{Wt}(+\mathrm{FF})$ & $\mathrm{Wt}(-\mathrm{FF})$ & & \\
\hline 24 & 2 & $1.00 \pm 0.10^{\mathrm{a}}$ & $0.85 \pm 0.05$ & $1.05 \pm 0.15$ & $0.75 \pm 0.15$ & $0.85 \pm 0.15$ & $0.85 \pm 0.15$ \\
\hline 26 & 2 & $0.95 \pm 0.05^{\mathrm{a}}$ & $0.80 \pm 0.00$ & $1.00 \pm 0.00$ & $0.70 \pm 0.10$ & $0.70 \pm 0.10$ & $0.95 \pm 0.05$ \\
\hline 28 & 2 & $1.90 \pm 0.40^{\mathrm{b}}$ & $1.15 \pm 0.25$ & $1.95 \pm 0.25$ & $0.80 \pm 0.10$ & $1.45 \pm 0.35$ & $1.30 \pm 0.30$ \\
\hline 30 & 2 & $1.20 \pm 0.00^{\mathrm{ab}}$ & $1.00 \pm 0.10$ & $2.25 \pm 0.75$ & $0.85 \pm 0.25$ & $0.85 \pm 0.25$ & $1.75 \pm 1.15$ \\
\hline Mean & & $1.26 \pm 0.16$ & $0.95 \pm 0.07$ & $1.65 \pm 0.26$ & $1.06 \pm 0.27$ & $0.96 \pm 0.14$ & $1.21 \pm 0.26$ \\
\hline
\end{tabular}

PP: postpartum: ROV: right ovary: LOV: left ovary; Wt(+ FF): weight of intact ovary plus follicular fluid; $\mathrm{Wt}(-$ FF): weight of ovary minus follicular fluid; a,b: values with different superscripts within column were significantly different $(\mathrm{P}<0.05)$.

Table 2. Mean ( \pm SEM) Dimensions of Ovaries of Savanna Brown Goats between Day 24 and 30 Postpartum

\begin{tabular}{|c|c|c|c|c|c|c|c|}
\hline \multirow[b]{3}{*}{ Days PP } & \multirow[b]{3}{*}{$\mathrm{n}$} & \multicolumn{6}{|c|}{ Ovarian dimensions } \\
\hline & & \multicolumn{2}{|c|}{ Length (cm) } & \multicolumn{2}{|c|}{ Height $(\mathrm{cm})$} & \multicolumn{2}{|c|}{ Breadth $(\mathrm{cm})$} \\
\hline & & ROV & LOV & ROV & LOV & ROV & LOV \\
\hline 24 & 2 & $1.75 \pm 0.25$ & $1.65 \pm 0.35$ & $1.00 \pm 0.00$ & $1.00 \pm 0.10$ & $0.40 \pm 0.10$ & $0.30 \pm 0.00$ \\
\hline 26 & 2 & $1.70 \pm 0.10$ & $1.80 \pm 0.20$ & $0.85 \pm 0.05$ & $0.90 \pm 0.10$ & $0.35 \pm 0.05$ & $0.50 \pm 0.20$ \\
\hline 28 & 2 & $1.90 \pm 0.10$ & $1.90 \pm 0.10$ & $1.18 \pm 0.00$ & $1.15 \pm 0.05$ & $0.50 \pm 0.00$ & $1.65 \pm 0.25$ \\
\hline 30 & 2 & $1.80 \pm 0.30$ & $2.30 \pm 0.10$ & $0.90 \pm 0.20$ & $0.90 \pm 0.10$ & $0.55 \pm 0.15$ & $0.55 \pm 0.25$ \\
\hline Mean ( \pm & & $1.79 \pm 0.08$ & $1.91 \pm 0.18$ & $0.96 \pm 0.05$ & $0.99 \pm 0.05$ & $0.45 \pm 0.05$ & $0.50 \pm 0.09$ \\
\hline
\end{tabular}

PP: postpartum; ROV: right ovary; LOV: left ovary.

Table 3. Mean ( \pm SEM) Count Numbers and Diameter of the Ovarian Follicles of Savanna Brown Goats between Day 24 and 30 Postpartum

\begin{tabular}{|c|c|c|c|c|c|c|c|}
\hline \multirow[t]{2}{*}{ Days PP } & \multirow[t]{2}{*}{$\mathrm{n}$} & \multicolumn{2}{|c|}{$\begin{array}{c}\text { Number of follicles } \geq 0.3 \mathrm{~cm} \text { in } \\
\text { diameter }\end{array}$} & \multicolumn{2}{|c|}{$\begin{array}{c}\text { Number of follicles }<0.30 \mathrm{~cm} \text { in } \\
\text { diameter }\end{array}$} & \multicolumn{2}{|c|}{$\begin{array}{l}\text { Diameter of the largest follicle } \\
(\mathrm{cm})\end{array}$} \\
\hline & & ROV & LOV & ROV & $\mathrm{LOV}$ & ROV & LOV \\
\hline 24 & 2 & $1.50 \pm 0.05^{\mathrm{ab}}$ & $2.00 \pm 1.00$ & $1.45 \pm 2.50$ & $17.5 \pm 2.05$ & $0.40 \pm 0.00^{\mathrm{ab}}$ & $0.50 \pm 0.10$ \\
\hline 26 & 2 & $0.05 \pm 0.05^{\mathrm{a}}$ & $2.50 \pm 0.50$ & $2.50 \pm 0.50$ & $9.50 \pm 4.50$ & $0.25 \pm 0.05^{\mathrm{a}}$ & $0.45 \pm 0.15$ \\
\hline 28 & 2 & $2.50 \pm 1.50^{\mathrm{ab}}$ & $4.00 \pm 0.00$ & $4.00 \pm 0.00$ & $25.00 \pm 10.00$ & $0.60 \pm 0.10^{\mathrm{b}}$ & $0.45 \pm 0.05$ \\
\hline 30 & 2 & $5.50 \pm 1.50^{\mathrm{b}}$ & $3.00 \pm 1.00$ & $3.00 \pm 1.00$ & $12.00 \pm 2.00$ & $0.40 \pm 0.05^{\mathrm{ab}}$ & $0.55 \pm 1.15$ \\
\hline Mean $( \pm$ SEM $)$ & & $2.50 \pm 0.82$ & $2.88 \pm 0.40$ & $14.00 \pm 2.38$ & $16.00 \pm 3.09$ & $0.43 \pm 0.05$ & $0.49 \pm 0.05$ \\
\hline
\end{tabular}


PP: postpartum; ROV: right ovary; LOV: left ovary; a,b: values with different superscripts within columns were significantly different $(\mathrm{P}<0.05)$.

Table 4. Mean ( \pm SEM) Volumes and Weights of Follicular Fluid in the Ovaries of Savanna Brown Goats between Day 25 and 30 Postpartum

\begin{tabular}{|c|c|c|c|c|c|c|c|}
\hline \multirow[t]{2}{*}{ Days } & \multirow[t]{2}{*}{$\mathrm{n}$} & \multicolumn{2}{|c|}{$\begin{array}{l}\text { Volume of fluid in the largest } \\
\text { follicle }(\mathrm{ml})\end{array}$} & \multicolumn{2}{|c|}{$\begin{array}{l}\text { Volume of fluid in all follicles } \\
(\mathrm{ml})\end{array}$} & \multicolumn{2}{|c|}{ Weight fluid in all follicles (g) } \\
\hline & & ROV & LOV & ROV & LOV & ROV & LOV \\
\hline 24 & 2 & $0.02 \pm 0.00$ & $0.48 \pm 0.42$ & $0.02 \pm 0.01$ & $10.9 \pm 0.90$ & $0.15 \pm 0.05^{\mathrm{a}}$ & $0.30 \pm 0.00^{\mathrm{a}}$ \\
\hline 26 & 2 & $0.02 \pm 0.00$ & $0.06 \pm 0.02$ & $0.20 \pm 0.10$ & $0.14 \pm 0.05$ & $0.15 \pm 0.05^{\mathrm{a}}$ & $0.30 \pm 0.10^{\mathrm{a}}$ \\
\hline 28 & 2 & $0.09 \pm 0.03$ & $0.08 \pm 0.02$ & $0.24 \pm 0.06$ & $0.31 \pm 0.11$ & $0.75 \pm 0.15^{\mathrm{b}}$ & $1.20 \pm 0.20^{\mathrm{b}}$ \\
\hline 30 & 2 & $0.04 \pm 0.02$ & $0.06 \pm 0.02$ & $0.17 \pm 0.05$ & $0.10 \pm 0.02$ & $0.20 \pm 0.10^{\mathrm{a}}$ & $0.20 \pm 0.10^{\mathrm{a}}$ \\
\hline Mean & & $0.04 \pm 0.13$ & $0.17 \pm 0.10$ & $0.18 \pm 0.03$ & $0.40 \pm 0.22$ & $0.31 \pm 0.10^{\mathrm{a}}$ & $0.49 \pm 0.16^{\mathrm{b}}$ \\
\hline
\end{tabular}

PP: postpartum; ROV: right ovary; LOV: left ovary; a,b: values with different superscripts within column were significantly different $(\mathrm{P}<0.05)$.

Table 5. Mean ( \pm SEM) Weights and Dimensions of Uterine Horns of Savanna Brown Goats between Day 24 and 30 Postpartum

\begin{tabular}{|c|c|c|c|c|c|c|c|c|c|}
\hline \multirow[b]{3}{*}{$\begin{array}{l}\text { Days } \\
\text { PP }\end{array}$} & \multirow[b]{3}{*}{$\mathrm{n}$} & \multicolumn{2}{|c|}{ Uterine horn Weight $(\mathrm{g})$} & \multicolumn{6}{|c|}{ Uterine horn Dimensions $(\mathrm{cm})$} \\
\hline & & \multirow[t]{2}{*}{$\mathrm{RH}$} & \multirow[t]{2}{*}{$\mathrm{LH}$} & \multicolumn{3}{|c|}{$\mathrm{RH}$} & \multicolumn{3}{|c|}{$\mathrm{LH}$} \\
\hline & & & & $\mathrm{L}$ & $\mathrm{D}$ & $\mathrm{Th}$ & $\mathrm{L}$ & $\mathrm{D}$ & $\mathrm{Th}$ \\
\hline 24 & 2 & $12.45 \pm 6.10$ & $11.70 \pm 3.60$ & $9.50 \pm 3.00$ & $2.00 \pm 0.00$ & $0.25 \pm 0.05$ & $10.65 \pm 2.65$ & $2.00 \pm 0.00$ & $0.25 \pm 0.05$ \\
\hline 26 & 2 & $12.60 \pm 0.40$ & $12.00 \pm 0.05$ & $10.25 \pm 1.25$ & $1.65 \pm 0.15$ & $0.40 \pm 0.10$ & $10.15 \pm 1.15$ & $1.65 \pm 0.15$ & $0.05 \pm 0.03$ \\
\hline 28 & 2 & $10.70 \pm 2.30$ & $11.00 \pm 2.40$ & $10.40 \pm 0.10$ & $1.70 \pm 0.10$ & $0.30 \pm 0.00$ & $9.25 \pm 0.25$ & $1.65 \pm 0.15$ & $0.20 \pm 0.00$ \\
\hline 30 & 2 & $15.65 \pm 5.70$ & $17.60 \pm 7.50$ & $11.35 \pm 3.35$ & $2.00 \pm 0.00$ & $0.35 \pm 0.05$ & $12.00 \pm 3.00$ & $2.00 \pm 0.00$ & $0.40 \pm 0.10$ \\
\hline Mean( & & $12.85 \pm 1.76$ & $13.04 \pm 1.91$ & $10.38 \pm 0.92$ & $1.84 \pm 0.07$ & $0.33 \pm 0.03$ & $10.51 \pm 0.87$ & $1.83 \pm 0.08$ & $0.29 \pm 0.04$ \\
\hline
\end{tabular}

PP: postpartum; RH: right uterine horn; LH: left uterine horn; L: length; Dm: diameter; Th: thickness

Table 6. Mean ( \pm SEM) Weights and Dimensions of Cervix and Uterine Body of Savanna Brown Goats between Day 24 and 30 Postpartum

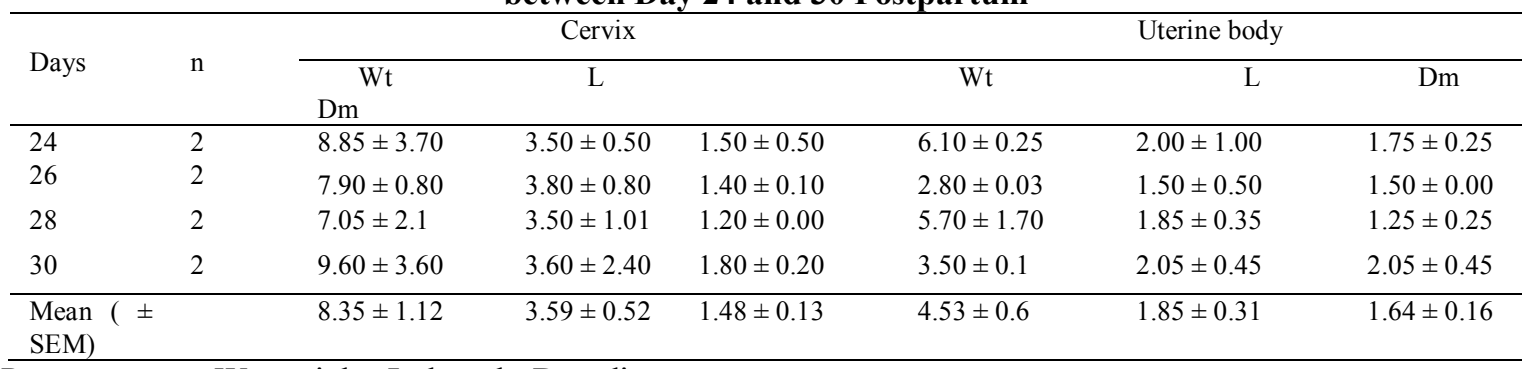

PP: postpartum; Wt: weight; L: length; Dm: diameter

Table 7. Mean ( \pm SEM) Dimensions of the Oviducts and Uterine Caruncles of Savanna Brown goats between Days 24 and 30 Postpartum

\begin{tabular}{|c|c|c|c|c|c|c|c|c|c|c|}
\hline \multirow{3}{*}{ Days PP } & \multirow{3}{*}{$\mathrm{n}$} & \multicolumn{2}{|c|}{ Caruncular diameter } & \multicolumn{2}{|c|}{ Inter-caruncular distance } & \multicolumn{5}{|c|}{ Oviducts } \\
\hline & & \multirow[t]{2}{*}{ RH } & \multirow[t]{2}{*}{$\mathrm{LH}$} & \multirow[t]{2}{*}{ RH } & \multirow[t]{2}{*}{$\mathrm{LH}$} & \multicolumn{2}{|c|}{ Rovid } & \multicolumn{3}{|c|}{ Lovid } \\
\hline & & & & & & $\mathrm{Wt}$ & $\mathrm{L}$ & & $\mathrm{Wt}$ & \\
\hline 24 & 2 & $0.45 \pm 0.5$ & $0.45 \pm 0.05$ & $0.30 \pm 0.05^{\mathrm{a}}$ & $0.25 \pm 0.05^{\mathrm{a}}$ & $0.15 \pm 0.05$ & $\begin{array}{l}13.50 \\
1.00\end{array}$ & \pm & $1.05 \pm 0.65$ & $14.00 \pm 0.50^{\mathrm{ab}}$ \\
\hline 26 & 2 & $0.50 \pm 0.00$ & $0.50 \pm 0.00$ & $0.60 \pm 0.20^{\mathrm{ab}}$ & $0.65 \pm 0.05^{\mathrm{b}}$ & $0.15 \pm 0.05$ & $\begin{array}{l}15.30 \\
0.50\end{array}$ & \pm & $0.45 \pm 0.05$ & $12.00 \pm 1.00^{\mathrm{a}}$ \\
\hline 28 & 2 & $0.35 \pm 0.05$ & $0.40 \pm 0.09$ & $0.50 \pm 0.10^{\mathrm{ab}}$ & $\begin{array}{l}0.55 \\
0.15^{\mathrm{ab}}\end{array}$ & $0.75 \pm 0.15$ & $\begin{array}{l}13.75 \\
1.75\end{array}$ & \pm & $1.08 \pm 0.20$ & $13.75 \pm 0.25^{\mathrm{ab}}$ \\
\hline 30 & 2 & $0.40 \pm 0.10$ & $0.45 \pm 0.05$ & $0.90 \pm 0.00^{\mathrm{b}}$ & $0.90 \pm 0.10^{\mathrm{b}}$ & $0.20 \pm 0.10$ & $\begin{array}{l}15.07 \\
1.75 \\
\end{array}$ & \pm & $1.20 \pm 0.40$ & $15.75 \pm 1.25^{\mathrm{b}}$ \\
\hline Mean $( \pm$ SE $)$ & & $0.43 \pm 0.03$ & $0.45 \pm 0.03$ & $0.58 \pm 0.09$ & $0.59 \pm 0.10$ & $0.31 \pm 0.10$ & $\begin{array}{l}14.31 \\
0.48 \\
\end{array}$ & \pm & $0.93 \pm 0.18$ & $13.88 \pm 0.60$ \\
\hline
\end{tabular}

PP: postpartum; RH: right uterine horn; LH: left uterine horn; Rovid: right oviduct; Lovid: left oviduct; a,b: superscripts within column were significantly different $\quad(\mathrm{P}<0.05)$. 